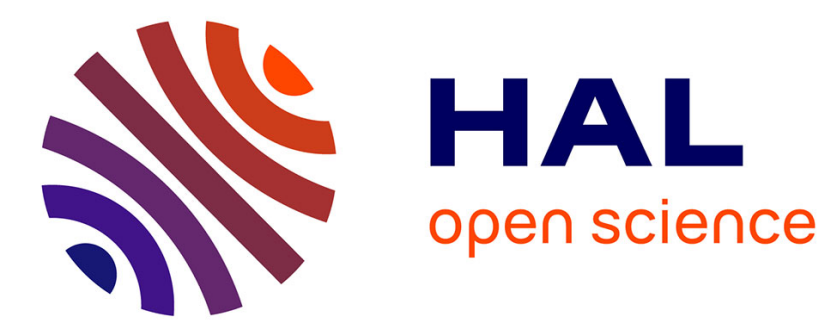

\title{
Integrating sustainable development in value models in entrepreneurship
}

Christophe Schmitt

\section{To cite this version:}

Christophe Schmitt. Integrating sustainable development in value models in entrepreneurship. Projectics / Proyéctica / Projectique, 2017, 3 (18), pp.107-122. 10.3917/proj.018.0107 . hal-02365614

\section{HAL Id: hal-02365614 \\ https://hal.univ-lorraine.fr/hal-02365614}

Submitted on 6 Dec 2020

HAL is a multi-disciplinary open access archive for the deposit and dissemination of scientific research documents, whether they are published or not. The documents may come from teaching and research institutions in France or abroad, or from public or private research centers.
L'archive ouverte pluridisciplinaire HAL, est destinée au dépôt et à la diffusion de documents scientifiques de niveau recherche, publiés ou non, émanant des établissements d'enseignement et de recherche français ou étrangers, des laboratoires publics ou privés. 


\title{
INTEGRATING SUSTAINABLE DEVELOPMENT IN VALUE MODELS IN ENTREPRENEURSHIP
}

\section{Christophe Schmitt}

\author{
University of Lorraine \\ IAE of Metz and CEREFIGE
}

\section{ABSTRACT}

The article focuses on the value models in entrepreneurship and, particularly, in a perspective of sustainable development. In the first part, we show that the different economic models do not take into consideration the sustainable development dimension.
Indeed, they are mainly concerned with the design of value, the production of value, or the valuation of value. The second part aims to propose a renewed vision of the models of value through the concept of complexity. In this perspective, we propose to apprehend several approaches allowing to link these three dimensions. In fact, our objective is to envisage the integration of the sustainable development dimension in order to propose a global model of value. The article will be ended by addressing the challenges to be considered in order to grasp the meaning of value in a global way.

Keywords: Value, Value models, Sustainable development, Global value, Complexity

This article aims to focus on the potential links between sustainable development and value models. Although the concept of sustainable development has largely invaded the discourse of practitioners, policymakers and researchers (Reynaud, 2010), little research has shed light on value models in entrepreneurship and even less on the role of sustainable development in such models. This is why we would like to give special attention to these models as the entry point to this article. Although value models are 
not sufficiently covered in the current debate on sustainable development (Berger-Douce, 2007), they have largely been of interest to economists. They represent a key element to the economic development of companies and nations. Nevertheless, value models are "dissolved" in management studies in general, entrepreneurship studies in particular, at the expense of other concepts such as the business model, focusing on how a company generates its revenues (Chanal, 2011). Nowadays, the concept of value seems to come across some thoughts that integrate it into the business model (Osterwalder and Pigneur, 2011). However, studies on the different value models attributed to entrepreneurial practices, that is to say, reflecting a set of practices with a view to value creation, is still poor (Schmitt, 2010). The one we propose in this article falls within in a twofold movement through an interdisciplinary and multidisciplinary opening (economics and management): extending the tradition of economists of working on value models and providing an approach for the understanding of value creation in entrepreneurship. The uniqueness of this article also covers the field of thinking that entrepreneurship represents. In fact, research studies on value models have largely focused on big companies (Montebello, 2003) and marginally on SMEs (Schmitt, 2010). Little evidence exists to address the relation between entrepreneurship and value models. It is within this scientific context that we have sought to understand the relationship between sustainable development and value models in entrepreneurship. More specifically, we are trying to provide an answer to the following question: Can sustainable development be considered as a value model in the field of entrepreneurship? The stakes are high since it is about shifting from a static and dominant economic model to a comprehensive and dynamic model.

In order to answer such question, we have divided our thoughts into two parts based on the concept of value models. The objective of the first part is to provide an overview of the different value models which have marked out the economic development over the past three centuries. We will particularly show that these models are designed through an implicit assumption of separation between supply and demand and that they are, above all, economic-based. We will also talk about economic value models. These models, although converging in terms of understanding the construction of value, remain nonetheless limited in their ability to recognize the complexity in which entrepreneurs develop. The second part will shed light on the necessary conditions for sustainable development to be considered as a global value model in entrepreneurship. We will address at a later stage the need, to consider sustainable development as a global value model, to change perspective, in other words to step out of the purely economic dimension of value models. It is an invitation to examine the complexity of sustainable development and, particularly, the interactions between the three pillars of sustainable development. Finally, we will show that the representation of the entrepreneur in terms of sustainable development is a key element in the development of a global value model in entrepreneurship. 


\section{CONVERGING YET LIMITED ECONOMIC VALUE MODELS}

While the studies of researchers and the speeches of practitioners focus on the business model, it is interesting to position oneself at a different level to understand which value models globally guide initiatives adopted by entrepreneurs. The emergence of these value models mainly relates to an approach based on the work of economists, particularly classical economists. Later, these approaches have been thoroughly examined in the field of economy and have contributed to disciplinary openness, as in business (Bréchet and Desreumaux, 1998). However, at the level of business in general, and entrepreneurship in particular, value models haven't played a key role in the development of research. Yet, being aware of value models helps understand the various ways in which organizations are considered. Moreover, these different value models are not neutral in the broader landscape of entrepreneurship. Not only do they help understand the relevant business practices, as we have just mentioned, but also the practices adopted in guiding entrepreneurship, practices at the level of entrepreneurship teaching or value models having an influence on policy decision-making in entrepreneurship.

\section{The coexistence of the three economic value models}

The three value models, which are the realization model, the valuation model and the conception model, continue to exist and coexist in the field of business in general, and entrepreneurship in particular. The emphasis we propose here is mainly chronological; it helps underline the foundations and emergence context of these models. The emergence and coexistence of these different value models in entrepreneurship reflect the dynamics of value over time (Schmitt, 2010).

The first model which was highlighted by economists is that of realization. This value model primarily focuses on the concept of supply. The realization model has its origins in the value of work developed by classical economists such as Smith (1723-1790), Ricardo (1772-1823) and Marx (1818-1883). In general, economists draw upon the claim that "the value of a property is equal lor proportional) to the amount of work required to produce it" (Perrin, 2001). The link between value models and entrepreneurship was established by Cantillon (1680-1734) and Say (1767-1832) who can be both regarded as pioneers for attributing a specific economic role to the entrepreneur in the economic process. Through this approach to value, we can particularly find entrepreneurs who develop in oligopolistic sectors where demand is greater than supply. This particularly resembles craft compared to some skills, notably to computing before the Internet bubble, to the construction industry, to the automobile or transportation sector. The development of this realization-based value model results in promoting the development of research on the entrepreneur. The 
value model was supported by studies carried out by the behaviorist trend in entrepreneurship. These behavioral and personality research studies focus on the following main question: "Who is the entrepreneur?". Underlying this issue, and in terms of the realization model (Hernandez, 1999), it is a question of identifying within a population people who are more likely than others to create value and help bring out the characteristics of creators who managed to create value compared to those who fail to do so. The realization-based value model is currently supported by studies on effectuation (Sarasvathy, 2008). Through this approach, we should be able to answerg the question raised by a large number of entrepreneurs, "What can I do?". The objective here is to start with the means available to the entrepreneur to create value.

Always centered on supply, the following value model that emerged is the conception model. Popularized by the works of Joseph Schumpeter (1883-1950), who attributed a badge of honor to the entrepreneur. The works of Schumpeter (1928) are permanently associated with the concepts of entrepreneurship and innovation: "The essence of entrepreneurship lies in the perception and exploitation of new opportunities in the realm of business [...]" (Filion, 1997: 3). Without being necessarily situated in a business creation perspective, the contribution of Schumpeter in this field is yet significant. In fact, innovation is considered as an important source of value creation (Dalohoun et al., 2009). It should be noted here that innovation is not simply the developed product and/or service. This value model, unlike the realization model which was based on the issue of doing, addresses the issue of the entrepreneurs' ability to design products and services. The development of this value model will continue over time, particularly through the works on creativity (Carrier and Gélinas, 2011). Through this value model, emphasis will be often placed on elements which help remove the bottlenecks that constrain innovation (technical knowledge, financial means, user acceptance, etc.). Again, this value model is found in different industries. In fact, it is a source of differentiation in relation to the existing supply. However, the degree of innovation will vary depending on the industry. For example, the number of innovations in the $I T$, telephony or power sector is not the same as in the energy sector.

The third and last economy-based value model is the complete opposite of the first two models. While the first two value models are centered on supply, the third one is based on demand. It is the valuation model according to which value is lastingly embedded in a dual perspective between supply and demand. Rejecting the objectivity of earlier studies (Mouchot, 1994), the socalled "marginal" trend, established particularly around Walras (1834-1910), Pareto (1848-1923) and Jevons (1835-1882), "establishes the idea that the value is a useful / rarity value which appears in the exchange, in terms of what the individuals themselves value, mediating between pleasure [obtained] and pain [avoided by the use of this property]" (Bréchet and Desreumaux 1998). This trend builds on the sensualist theory of Condillac (1756/2001) according to which a certain item does not have value because it costs, but it costs because it has value. The neoclassical paradigm emphasizes the importance of exchange and the leading role of demand in response to the supply proposals, that is to say satisfaction brought by the use of property. Not only does the emergence of the value model help taking the buyer into consideration at 
the entrepreneurial level, but also contributes to the society's socio-economic development. This conception of value creation takes into account the fact that the client is a requester, user and assessor of value. The client no longer appears only as the ultimate sanction (whether or not to purchase a product), but also as a participant in the value creation process. This holds true given the $B$ to $B$ relations where clients are few and take part in the development of products and services. This co-construction of value has become widespread in the $90 \mathrm{~s}$ by the involvement of users in the development of computer software. This valuation model is also currently found in business models that focus on users. This is particularly the case of consumers who purchase through subscription, often yearly, their consumption of fruits and vegetables, or the websites funded by advertising based on the number of web visitors. Invoking the market also means attributing a prominent role to the judgments of clients and/or users, particularly through the price of products or services. The biggest challenge for entrepreneurs is then to better understand the market and, more particularly, when the latter is volatile, and to share this understanding of the market with the stakeholders of the entrepreneurial project. Through this value model, researchers have mainly sought to answer the question "What does the entrepreneur do?", specifically in relation to his environment.

\section{Synthesis among the various economic value models: always more about the same thing}

Based on these various economic value models in entrepreneurship, studies have been conducted in economics and in business in order to make a synthesis out of them. Two types of synthesis should be pointed out: the first type of synthesis that appeared in time is about the theoretical separation among value models dealing with supply and those dealing with demand. Some authors have attempted, particularly in economy, to overcome such dichotomy, as we can see for example in the works of Say (Traité d'économie politique) and Marshall (1842-1924) (The Principles of Economics). The first considers that "the value of each thing is the result of contradictory evolution between the one who needs it and the one who produced it" (Perrin, 2001:25). The second schematically considers value as the two blades of a pair of scissors, on one side the demand reflects the satisfaction provided to consumers; on the other, supply reflects the choice of the producer, particularly in terms of production costs. Marshall (1890/2009) added that "it is just as unreasonable to dispute whether it is the upper or the under blade of a pair of scissors that cuts a piece of article, as whether value is governed by utility or cost of production". The works of Say and Marshall contribute to the theory of value based on the merging between the production point of view and the demand point of view. They serve not only to rebalance the relationship between the company and the client, but also to consider the approaches on supply and demand as part of the same reality. From an entrepreneurial perspective, we find the mindset of nonseparability between supply and demand, particularly through the concept of value chain developed by Porter (1982). In this perspective, it is not possible to attribute to one or another stakeholder in the entrepreneurial 
project a quantifiable contribution in terms of the product value (Lorino, 1997). We go beyond the myth of the homo œconomicus, wherein the entrepreneur is considered individualistic and rational (Goglio, 2005). The initial stages of the global value also emerge. We find here a foundation that will help get rid of the economic perspective of entrepreneurship: the social dimension of entrepreneurship (Zafirovski, 1999; Jones and Wadhwani, 2006).

As for the second type of synthesis, it proposes to consider the relationship among the three economic value models (Schmitt, 2010). Based on a dialectical approach to value (Schmitt, 2010), this model seeks to show potential links among the three economic value models. It appears therefore that the importance of conception lies in the fact that it is defined, not based on the separation between supply and demand, but precisely at the interface, between the internal and external environments of the entrepreneur. Therefore, the dialectic value differs from other approaches to value insofar as it is no longer limited to the company-client relationship, but rather embedded in a recursive and scalable relational triptych. It reflects the asymmetry between the client's position and that of the entrepreneur (Lorino, 1997), corresponding to the uncertain and risky nature of the concept of value. This approach to value refers therefore to the autonomy of corporate actors to meet the market needs.

Hence, the construction of value develops around the three following relationships:

- The first connects the client to conception through vision. It is the entrepreneur's vision in terms of anticipating the clients' judgement. This relationship is characterized above all by its strategic aspect. The anticipated risky judgement on the client's judgement seems to be a starting point of the dialectic value.

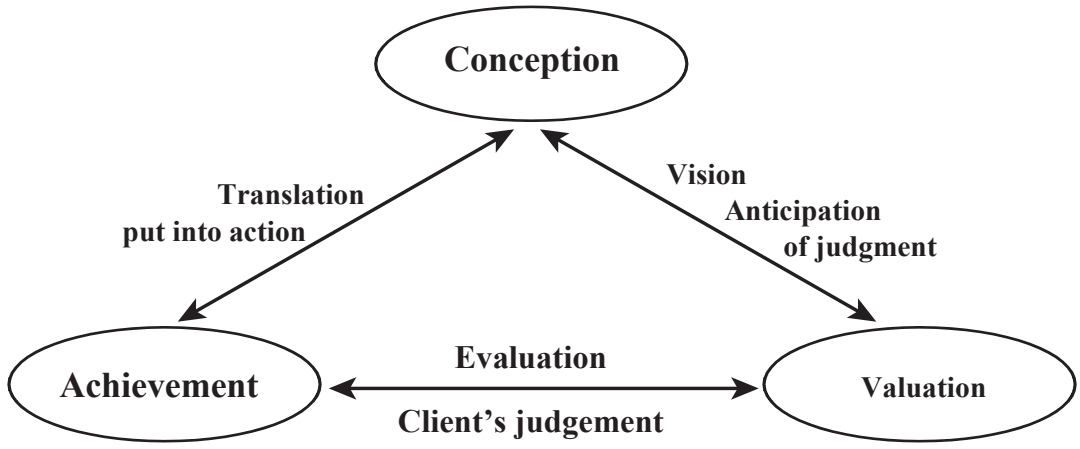

Figure 1. The dialectic value: synthesis of the three economic value models (Schmitt, 2010)

- The second relationship involves conception and realization, through the translation of the entrepreneur's vision. In order to succeed, conception cannot do without realization. As Boutinet (1993:26) highlights it, "the design of 
conception should be materialized in a drawing of achievement, which will modify, correct the initial design, the latter leading to a new realization." The anticipation by the entrepreneur needs to be translated into concrete actions within the company. There may be differences between conception and realization, between design and drawing. These differences are mainly due to problems in translating the entrepreneur's vision to the stakeholders concerned with the entrepreneurial project.

- The third relationship is that of the client's judgement. This last point is associated with the sanction of the market. Therefore, not only will value depends on the client's judgement, but also on the anticipation of this judgement by the entrepreneur (design), as well as the decisions resulting thereof and the implementation of those decisions (drawing). As Lorino (1997) notes, it is clear that "in most cases, the distance is big between value assessment (price, quality and competitiveness of offered products and services) and the operational management of internal business".

This dialectical value model allows us to examine the economic value in a global manner at the level of an entrepreneurial project. Currently, demands of the entrepreneurial projects stakeholders will no longer position themselves on a dimension of value, but rather on the entire value creation process in a non-breaking perspective.

\section{Limits of the economic value models}

Although they help go beyond the traditional approaches to the concept of value, these contributions remain limited in a certain number of points. Three main criticisms can be raised. The first is concerned with the construction of entrepreneurship research field. Entrepreneurship, since its emergence as a study subject, has been the subject of an approach characterized by its irreconcilable duality between value models based on supply and those based on demand. The different traditional approaches to entrepreneurship are never more than partial explanations of the examined phenomenon. It is therefore necessary to go beyond this duality and consider entrepreneurship through the action itself and not through the result of the action. This duality helps us understand the difficulties in finding consensus in terms of the definitions of entrepreneur and entrepreneurship. The second criticism relates to the dominant framework. Both models which offer a synthesis do not break with the dominant framework, since they do not propose to go beyond the limited relationship around the economic value models. Understanding and grasping the concept of value highlight the need to propose a different perspective, one that helps overcome the economic approach to value in the field of entrepreneurship. The failure of the approaches to value to propose a vision that would help go beyond the dominant economic framework is mainly due to an implicit assumption of separability between supply and demand. Since such assumption is becoming 
increasingly difficult to sustain, it is necessary to consider the notion of value differently. The third criticism that can be raised with regards to the economic value models is the absence or the quasi-absence in the literature on entrepreneurship of other dimensions other than this economic dimension. It can be argued that studies on entrepreneurship have been therefore blindly structured around the economic dimension of value, ignoring other dimensions until recently, for example, the environmental and social dimensions of entrepreneurship. This implies that the field of entrepreneurship has rarely been considered in its complexity and that we have strongly neglected the human capacity in conceiving an organization and imagining it in the future.

In light of these various components, it is necessary to develop research that takes into account the complexity of the entrepreneurial phenomenon, in order to develop a value model that goes beyond the purely economic dimension and takes other dimensions into consideration. Hence, it is necessary to focus not only on what the entrepreneur is and what he does, but rather on how the entrepreneur creates value, that is to say how he organizes his thoughts to define an entrepreneurial system of actions within an environment characterized by complexity (Filion, 1997).

If the patterns of conventional approaches to entrepreneurship throughout the various value models are questionable in theory and too limited to understand empirical phenomena, we must seek other ways to understand the entrepreneurial phenomenon in order to propose action components more appropriate to the reality perceived by entrepreneurs. One possible way is to consider the complexity of the entrepreneurial phenomenon as a structuring element of the organization that helps develop global value models. This is the objective of the second part of this article.

\section{THE PLACE OF SUSTAINABLE DEVELOPMENT IN VALUE MODELS IN ENTREPRENEURSHIP}

The concept of sustainable development has enriched in recent years the debates on entrepreneurship. This concept, recent from the point of view of research, can be considered as polymorphic, whose outlines remain under construction (Spence et al., 2007; Lizarralde, 2009). Often developed in research on big businesses, it is reasonable to conduct research on sustainable development, more specifically on entrepreneurship and SMEs. In fact, as shown by some authors (Dupuis and Bas, 2007; Berger-Douce and Schmitt, 2013), there is a size effect in practices in terms of sustainable development and the entrepreneur is the vector of sustainable development. Since the entry point to our considerations is value models, we will not discuss the concept of sustainable development by itself. Our thoughts will be limited to the three pillars of sustainable development: economic, environmental and social. Through these three pillars, we seek to underline three main points in the integration of sustainable development as a constituent element of a global 
value model in entrepreneurship. The first point will deal with the place of sustainable development in terms of value creation. We will particularly see the impact it can have depending on the chosen setting. The second point will address the importance of integrating theories of complexity in order to consider sustainable development as a global value model. Finally, the third point will address an important aspect of sustainable development as a global value model in entrepreneurship: the entrepreneur.

\section{Sustainable development as change in perspective in value models}

The underlying question that is raised with the emergence of this concept in the field of entrepreneurship refers to the place of sustainable development in value models. To understand this place, it is necessary to grasp the opportunities available to us to position the concept of sustainable development. In light of the first part of this article, if it is clear that it is necessary to go beyond the dominant framework, it is yet not quite easy to do so. By taking into consideration works on the change brought by the Palo Alto model (Watzlawick et al., 1975), it is possible to argue that the various developments of the value model in entrepreneurship presented in the first part belong type 1 changes. Whatever the chosen direction is, value models contribute to the development of the dominant framework: the economic value model. This amounts to propose changes that merely fit into the economic value paradigm, "always bringing more of the same thing" (Watzlawick et al., 1975: 121). Therefore, the economic value model in entrepreneurship acts as a meta-model incorporating the main models that have so far been developed. To go beyond such context, it is necessary to question this meta-model by making a type 2 change. This change leads to question the meta-model and redefine the existing rules. Thus, the economic value model is no longer regarded as the only way to approach the concept of value but as one way among many others. The fact of going beyond the dominant framework calls into question other aspects of value in order to take into account the complexity of the entrepreneurial phenomenon, as the concept of sustainable development urges us to do.

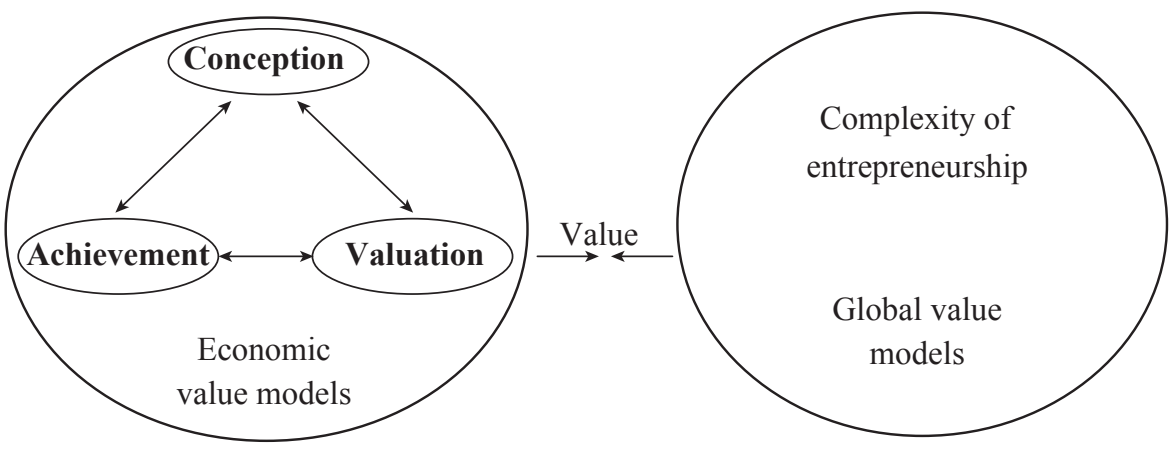

Figure 2. From economic value models to a global value model: a change in perspective 
In light of these ideas, there are two possible options: sustainable development considered as a type 1 change, or sustainable development considered as a type 2 change. In the first case, sustainable development is mainly thought of with a strategic perspective similarly to internalization, relocation, innovation, etc. In this case, sustainability is part of the existing economic value models. This possibility should not be underestimated in the reading of the literature on sustainable development in small enterprises. In other words, sustainable development may be judged as a mere fad, which will be integrated with time like any other fad within an economic value model. The components, in terms of both practice and research, are already reflecting that orientation. In terms of practice, studies show that in many cases entrepreneurs are limited to the pillars of sustainable development (Labelle, 2008; Berger-Douce, 2007). Furthermore, their perception is part of an additive reasoning (Bellini, 2003), without questioning the value model in which they exist. It is interesting to make parallels from this point of view with the literature on topics such as quality, supply chain, company-network and standby, insofar as entrepreneurs develop practices ranging from non-taking into consideration to pro-activity, going through re-activity. Studies have often shown that entrepreneurs are mostly in a non-taking into consideration or re-activity position in relation to the emergence of new management practices. In terms of theory, Capron and Quairel-Lanoizelée (2004:12) support this position, pointing out that research in the field of sustainable development focuses more on "economic and organizational theories such as the classical and liberal approach, the stakeholder theory, the dependency theory of resources or the neo-institutionalism theory". Even in terms of research on entrepreneurship, sustainable development is often associated with economic value models.

\section{Global value: complexity as a way to consider sustainable development}

As we have mentioned it in the previous paragraph, sustainable development, particularly in terms of entrepreneurship, is rarely considered through these three dimensions. Moreover, studies on the intersection areas between the three dimensions are rare (Capron and Quairel-Lanoizelée, 2004). These two factors suggest that the complexity of sustainable development is not taken into account in value models. Resorting to complexity should not be regarded as an "intellectual abdication company which affirms that everything is complex" (Weinberg, 1995:23), but as an opportunity to develop an appropriate value in the entrepreneurial context. The idea of complexity is paradoxically very simple (Morin, 1990). Indeed, it is overcoming the visible dualities (Barel, 1979) and taking into consideration the representations of the entrepreneur in light of his experiences (Schmitt, 2009). If we reconsider the thoughts of Morin, we would say that addressing complexity calls for adopting a method (Morin, 1977). This is why it is important to consider the methodological foundations of a global value model based on the three pillars of sustainable development.

Hence, considering the global value in terms of complexity leads us to highlight three methodological foundations while addressing the concept of global value in entrepreneurship: 
- The dialogical foundation: as underlined by Morin (1977), dual patterns should be certainly opposed (disconnected), but in the same time linked (connected). The interest to consider the various dimensions of sustainable development in a dialogical way helps not only integrate the characteristics associated with each of these dimensions, but also bring out specific characteristics related to the interlinking of these dimensions. Thus, four intersecting areas arise beside the three pillars. The economic value models follow instead an approach of separation and simplification.

- The dynamic foundation: the three pillars and the four intersecting areas which form the elements of sustainable development bring a great variety in the global value model. The interactions among these elements are many and they develop over time. The global value model should be considered as dynamic and not static. Not only do the three pillars of sustainable development evolve, but also the different interaction areas evolve as well. We can consider that value is the never-ending result of the interaction process among the various dimensions of sustainable development (Datta, 2011). The difficulty that faces the entrepreneur is in taking these interactions into account. This difficulty comes not only from their number but also from their dynamics.

- Intelligibility of the global model value: many authors emphasize the human dimension of sustainable development (Spence et al, 2007; Berger-Douce, 2007). Turning sustainable development into a global value model requires therefore taking this human dimension into consideration. The banker does not necessarily have the same representation of value as the entrepreneur and so on. The intelligibility of the global value model consists in managing to share its representation as an entrepreneur with the stakeholders of the entrepreneurial project. Making the complexity of value accessible helps us develop representations based on a process of modelling. Rather than starting "with simplifying" based on the various dimensions of value, it is a good idea to start "with modelling". The resulting tools are designed not to accurately represent the reality of the global value model, which seems to be, according to Lacroux (1999), a search for the "real", but rather to allow stakeholders to express its interpretation in order to facilitate the understanding of value. Modeling helps then make evolutionary projections, promoting the construction and implementation of scenarios for human action (Schmitt, 2009). In modeling, the entrepreneur builds a scenario of the value he would like to develop. This scenario is built based on consistent and plausible assumptions. This means that the way of 
building a scenario affects the model of the selected value. This scenario uses dialogue elements between the entrepreneur and the stakeholders of the entrepreneurial project through the planned value model.

\section{The representation of the entrepreneur as the construction element of a global value model in entrepreneurship}

Economic value models have been mainly focused on the "what / why" question (What can I do? What is the client's judgement? ...). The overall value model based on sustainable development raises a new question: the "how" (How does the entrepreneur who wants to create the overall value think? How to approach the complexity of entrepreneurship? ...). The development of such questions is not unreasonable; it rather reflects a semantic shift. As pointed out by von Foerster (2000), it is not a question of knowing what we learn, but rather knowing how we learn. The "how" question refers to our experience of knowledge (Schmitt, 2009) and, in our case, to the experience of sustainable development and value creation. The global value model in entrepreneurship can therefore be considered above all as a human construct in all its complexity. The fact of considering value as a human construct results in placing the entrepreneur at the center of value (Bossink, 2007), as if he is the orchestra conductor of the value construction. The human aspect can be found at different places in the overall value model, through the product or service offered by the entrepreneur, and also at the consumer level. This also applies to suppliers, competitors, funders, partners, public authorities, etc., where each has its own representation of value offered through the entrepreneurial project. Thus, all stakeholders play a role in the overall value model. At this level of thought, it should be noted that the roles are not the same for the entrepreneur and the stakeholders. The latter take part in the co-construction of value based on the entrepreneur's entrepreneurial project within a global value model.

The value made by the entrepreneur is often disregarded when looking at the concept of value in favor of an ontological perspective, that is to say through "an objective world that precedes our knowledge" (von Glasersfeld, 2000), corresponding to the "view of reality that we receive via our senses" (Watzlawick et al., 1975), related to our experiences, our convictions, our beliefs, our habits, etc. The global value model needs to be translated at the level of the stakeholders of the entrepreneurial project. The purpose of translation, according to Callon and Latour (1991), is to help these stakeholders, who have different perspectives, reach a common understanding of a global model of shared value. Translation promotes a certain collective regulation (Berger-Douce, 2007). Thus, when the value model focuses on a certain dimension, such as supply or demand, translation seems simple to implement. Contrariwise, if the selected value model is more global, such as based on the three pillars of sustainable development, it is important to make the complexity of the selected value model easier to understand. Translation is an important issue for the entrepreneur because the complexity of the selected value model 
cannot be transposable as it is. It often requires moving from an implicit level to an explicit level.

In order to address the difficulties related to translation, it is necessary to promote dialogue and consistency between the entrepreneur and the stakeholders of the entrepreneurial project. This requires the development of a common language and the presence of a translator in the value construction process. According to Bernoux (2004), the translation theory was one of the factors which helped develop the functioning per project practice in companies and organizations. However, the current problem lies in the establishment and development of this language, which might be called the language of "value", while stakeholders often speak "different" languages, and especially, "business" languages. More generally, the role of the translator mainly revolves around three elements: the establishment of a "value" language along with its terminology and grammar, the development and enrichment of this language, and finally its dissemination. Regarding the translator, it seems necessary that he should be the entrepreneur, being the only one with a global vision of his project and of the underlying value model.

\section{CONCLUSION}

This article has attempted to question the link between sustainable development and value models, and to examine whether sustainable development can be considered as an integral value model. To answer this question, we proposed at first to understand the evolution of value models through time. Thus, we have endeavored to show that these models have evolved over time, but ultimately, they revolved around the economic dimension of value. Whether we are talking about value models based on supply or on demand, both fall within the economic dimension of value. Models that offer a synthesis of both are also part of the economic dimension of value. In that respect, the emergence of the concept of sustainable development challenges the traditional value models. In the second part, we examined the necessary conditions to consider sustainable development as a global value model that goes beyond the mere economic dimension of value. In light of research studies on entrepreneurship and sustainable development, we have noticed that the practices of entrepreneurs are not yet fully part of a global value model. In fact, the overall value model based on the pillars of sustainable development is far from imposing itself compared to the practices firmly rooted in a purely economic dimension of value. The prospects of development are not limited to putting the two other missing pillars of sustainable development next to each other lenvironmental and social) in order to discuss the establishment of a global value model in entrepreneurship. Instead, the establishment of a global value model involves the need to change entrepreneurial practices. We highlighted three key points that should be implemented so we can talk about a global value model. The integration of sustainable development in terms of value models definitely requires a change in perspective. As evidenced by relevant studies, there is a high risk that sustainable development would be merely considered as part of an economic value model. After showing the necessary conditions for the 
change in perspective, we proposed a reading based on the theories of complexity (Morin, 1977). It is not a question of juxtaposing the three pillars of sustainable development, but rather that of examining the various interactions among these three pillars in a dialogical perspective. Finally, the last point particularly underlines that value creation is above all a human construct. This is clearly reflected in research by the transition from the "what/why" question to the "how". Such transition cannot be meaningless; it refers to the social and cognitive dimension of the entrepreneur and his ability to translate his vision to the stakeholders of his entrepreneurial project.

The consequences of change in perspective are not neutral, particularly at the level of funds and aids granted to projects in the field of social and sustainable economy. In fact, while funds and aids vested in corporate financing are mainly interested in the ROI (Return on Investment), corresponding to the economic value model, it is necessary to develop indicators related to the overall value model. This is important at the level of granting financing sources to avoid penalizing a whole business category that creates value in the area. This also applies at the political level that often offers public aids within the perspective of economic value. There is a whole new sector in the economy. This revolution must bring changes at the level of practices, and also at the level of politics and research. In this regard, interesting topics emerge as solidarity financing, socially responsible investment and crowdfunding, which are all interesting research avenues in the field of management.

\section{REFERENCES}

Barel, Y. (1979), Le paradoxe et le système, (The Paradox and the System), Presses Universitaires de Grenoble, Grenoble.

Bellini, B. (2003), Un nouvel enjeu stratégique: la prise en compte de la protection de l'environnement dans son management, (A New Strategic Challenge: Taking into Account the Protection of the Environment in its Management), Workshop on Sustainable Development organised by l'AIMS.

Berger-Douce, S., Schmitt, C. (2013), Entrepreneur Profile and Sustainable Innovation Strategy, in Ivanaj S., Ivanaj V., McIntyre J., Sustainable technologies and innovations, Edward Elgar Publishing, pp. 186-203.

Berger-Douce, S. (2007), Le management environnemental des PME rentables: une étude exploratoire en France, (Environmental Management of Profitable SMEs: an Exploratory Study in Francel, Revue Internationale PME, vol. 20, n³-4, pp. 165-190.

Bernoux, P. (2004), Sociologie du changement dans les entreprises et les organisations, (Sociology of Change in Entreprise and Organization), Le Seuil, nouvelle édition 2009, Paris.

Bossink, B.G. (2007), Leadership for Sustainable Innovation, International Journal Of Technology Management \& Sustainable Development, 6(2), pp. 135-149.

Boutinet, J.-C. (1993), Psychologie de la conduite à projet, (Psychology of Project Leading), PUF, Paris.

Bréchet, J.-P., Desreumaux, A. (1998), Le thème de la valeur en Sciences de Gestion. Transversalité, ambiguité et enjeux, Actes des XIV journées nationales des IAE, (The Theme of Value in Business Science. Transversality, Ambiguity and Goals), Nantes, pp. 7-12.

Callon, M., Latour, B. (1991), La science telle qu'elle se fait, (Science in its action), Paris, La Découverte.

Capron, M., Quairel-Lanoizelée, F. (2004), Mythes et réalités de l'entreprise responsable, (Myths and Realities of the Responsible Entreprise), Paris, La Découverte. 
Carrier, C., Gélinas, S. (2011), Créativité et gestion : les idées au service de l'innovation, (Creativity and Management: Ideas for Innovation), Presses de l'Université du Québec, Sainte-Foy.

Chanal, V. (2011), Business models dans l'innovation : pratiques et méthodes, (Business Models in Innovation: Practices and Methods), Presses Universitaires de Grenoble, Grenoble.

Condillac, E. (1756/2001), Essay on the Origin Human Knowledge, Editor Hans Aarsleff.

Dalohoun, D.N., Hall, A., \& Van Mele, P. (2009), Entrepreneurship as Driver of a Self-Organizing System of Innovation: the Case of NERICA in Benin, International Journal Of Technology Management \& Sustainable Development, 8(2), pp. 87-101.

Datta, P.B. (2011), Exploring the Evolution of a Social Innovation: A Case Study from India, International Journal Of Technology Management \& Sustainable Development, 10(1), pp. 55-75.

Dupuis, J.-C., Le Bas, C. (2007), Les leviers des démarches RSE en PME : cadre d'analyse et premiers résultats, (Levers of CSR Approaches in SMEs: Analysis Framework and Primary Results), Revue Internationale PME, vol. 20, n³-4, pp. 7-15.

Filion, L.-J. 1991), Visions et relations, (Visions and Relations), Éditions de l'entrepreneur.

Filion, L.-J. (1997), Le champ de l'entrepreneuriat : historique, évolution, tendances, (Entrepreneurship Field: History, Evolution, Trends), Revue Internationale PME, vol. 10, n², pp.129-172.

Foerster, H.von. (2000), Ethique et cybernétique de second ordre, (Ethics and Cybernetics of Second Order), in Watzlawick P. (coordination), L'invention de la réalité. Contributions au constructivisme, Seuil, pp. 60-76.

Forsé, M. (1989), L'ordre improbable, entropie et processus sociaux, (The Improbable Order, Entropy and Social Processes), P.U.F., Paris.

Glasersfeld, E. (1988), Introduction à un constructivisme radical, (Fundamentals of Radical Constructivism), in Watzlawick P. (coordination), L'invention de la réalité, contribution au constructivisme, Seuil, pp. 19-44.

Goglio, K. (2005), L'entrepreneur porteur de fausses représentations chez J.-B. Say, (When the Entrepreneur Carries False Representations According to J.-B. Sayl, in Problèmes Economiques, N²883, pp. 33-39.

Hernandez, E.-M. (1999), Modèles d'entrepreneuriat: vers une approche contingente et processuelle, (Entrepreneurship Models: Towards a Contingent and Processing Approach), Revue Sciences de Gestion, n²6-27, pp. 505-526.

Jones, G., Wadhwani, R.D. (2006), Entrepreneurship and Business History: Renewing the Research Agenda, Cahier de recherche, Cambridge, Harvard Business School.

Labelle, F. (2008), La PME et la durabilité : une gestion qui améliore les capacités d'innovation des entrepreneurs, (SMEs and Sustainability: How Management improves Entrepreneurs Innovation Capacities), CIFEPME, Louvain-la-Neuve.

Lacroux, F. (1999), La modélisation dans le contrôle de gestion, (Modeling in Management Control), in Faire de la recherche en contrôle de gestion ? coordonné par Dupuy. Y, Vuibert-Fnege, Paris, pp. 21-29.

Lizarralde, I. (2009), Cooperatism, Social Capital and Regional Development: the Mondragon Experience, International Journal Of Technology Management \& Sustainable Development, 8(1), pp. 27-38.

Lorino, P. (1997), Méthodes et pratiques de la performance, le guide du pilotage, (Methods and Practices of Performance, the Pilotage Guide), Les Editions d'Organisation, Paris.

Marshall, A. (1890/2009), Principles of Economis, Cosimo, Inc.

Montebello, M. (2003), Stratégie de création de valeur pour le client, (Customer Value Creation Strategy), Economica, Paris.

Morin, E. (1977), La méthode, (The Method) Tome I: “La nature de la nature”, Le Seuil, Paris.

Mouchot, C. (1994), Les théories de la valeur, (The Value Theory), Economica, Paris.

Osterwalder, A., Pigneur, Y. (2011), Business Models, nouvelle génération, (The New Generation of Business Models), Perason, Paris.

Perrin, J. (2001), Analyse de la valeur et valeur économique des biens et services, (Value Analysis and Economic Value of Goods and Services), Revue Française de Gestion Industrielle, n²/2001, Volume 20, juin, pp. 9-20. 
Porter, M. (1982), Choix stratégiques et concurrentiels, (Strategic and Competitive Choices), Economica, Paris.

Reynaud, E. (2010), Le management stratégique durable, (Sustainable Strategic Management), in Reynaud, E. Stratégies d'entreprises en développement durable, L'Harmattan, pp. 19-46.

Sarasvathy, S.D. (2008), Designing Organizations that Design Environments: Lessons from Entrepreneurial Expertise, Organization Studies, 29, n³, 2008, pp. 331-350.

Schmitt, C. (2010), La valeur des produits et des services en PME, (The Value of Products and Services in SMEs), Growth Publisher, Berne.

Schmitt, C. (2009), Les situations entrepreneuriales: une nouvelle grille d'analyse pour aborder l'entrepreneuriat, (Entrepreneurial Situations: a New Grid of Analysis to Apprehend Entrepreneurship), Revue Économie et Sociale (3), pp. 11-25.

Schumpeter, J. (1928), The Instability of Capitalism, The Economic Journal, 151, vol. XXXVIII, september, pp. 379.

Spence, M., Ben Boubaker Gherib, J., Ondua Biwolé, V. (2007), Développement durable et PME : une étude exploratoire des déterminants de l'engagement, (Sustainable Development and SMEs: An Exploratory Study of Commitment Determinants), Revue Internationale PME, vol. 20, $\mathrm{n}^{\circ} 3-4$, pp. 17-42.

Watzlawick, P., Weakland, J., Fisch, R. (1975), Change. Principles of Problem Formation and Problem Resolution, New-York, 1974, traduction française Changements. Paradoxes et psychothérapie, Editions du Seuil, Paris.

Weinberg, A. (1995), Les jeux de l'ordre et du désordre, (The Order and Disorder Games), Sciences Humaines, $n^{\circ}$ 47, février 1995, pp. 16-18.

Zafirovski, M. (1999), Probinginto the Social Layers of Entrepreneurship: Outline of the Sociology of Enterprise, Entrepreneurship and Regional Development, vol. 11, n 4, pp. 351-371.

Christophe SCHMITT is currently Vice-President of the University of Lorraine and a Professor of Entrepreneurship. He holds the Chair of Entrepreneurship at the University of Lorraine. He works in the field of student entrepreneurial culture development. His work focuses on the entrepreneurial process and the entrepreneurial cognition. He developed tools and methods such as IDéOC in order to evaluate the potential of business opportunities, and to establish links between projects promoters and the stakeholders. He has also written several scientific articles and published books about entrepreneurship. His latest book highlights the notion of Entrepreneurial Action. He is also an Associated Professor of CRIPMEE in Canada and a Visiting Professor at Louvain School of Management, Belgium and at Fribourg School of Management, Switzerland. christophe.schmittauniv-lorraine.fr https://fr.wikipedia.org/wiki/Christophe_Schmitt https://www.researchgate.net/profile/Christophe_Schmitt3 https://scholar.google.fr/citations?user=A5yfVVYAAAAJ \&hl=fr 